\title{
Embrace Fintech in ASEAN: A Perception Through Fintech Adoption Index
}

\author{
Alice Yong-Zheng Huong ${ }^{1}$, Chin-Hong Puah $^{1} \&$ Mei-Teing Chong ${ }^{1}$ \\ ${ }^{1}$ Faculty of Economics and Business, Universiti Malaysia Sarawak, Sarawak, Malaysia \\ Correspondence: Chin-Hong Puah, Faculty of Economics and Business, Universiti Malaysia Sarawak, Jalan Datuk \\ Mohammad Musa, 94300 Kota Samarahan, Sarawak, Malaysia. Tel: 60-82-584-294. E-mail: chpuah@unimas.my
}

Received: August 12, 2020

Accepted: October 26, 2020

Online Published: January 3, 2021

doi:10.5430/rwe.v12n1p1

URL: https://doi.org/10.5430/rwe.v12n1p1

\begin{abstract}
In this new age of financial technology developments in ASEAN, the financial services industry is evolving quickly. However, consumer intention to embrace financial technology in different financial services remains vague. Hence, this study aims to investigate the consumer Fintech adoption level through constructing a Fintech Adoption Index for ASEAN countries. The empirical findings reveal that Singapore with a mature Fintech development having a relatively high adoption rate, while countries with nascent Fintech development such as Brunei Darussalam, Cambodia, Myanmar and Laos have a relatively low adoption rate as compared to the countries with emerging Fintech development such as Indonesia, Malaysia, Philippines, Thailand and Vietnam. All ASEAN countries show increasing trends in Fintech adoption from 2017 to 2019. From this study, the dimensional and final index scores generated are easy to understand, and this study has successfully simplified the complexity of Fintech adoption level across different sub-sectors for all ten ASEAN countries. In conclusion, the newly constructed Fintech adoption index for ASEAN countries can better illuminate consumer adoption preference toward Fintech development and thus leverage the results for productive financial policy direction.
\end{abstract}

Keywords: fintech, ASEAN, fintech adoption index

\section{Introduction}

Fintech is an acronym for financial technology, integrating banking knowledge with modern management science techniques and computer technologies (Bettinger, 1972). The presence of Fintech is believed to boost economies of a country (Zhang et al., 2020). Todays, Fintech has expanded to be more than a start-up. It becomes a multitude of companies offering a wide variety of banking services and operating everywhere. Fintech has recently become the main development agenda for Association of Southeast Asian Nations (ASEAN). The financial services industry in ASEAN is developing quickly as a result of these new-age financial technology disruptions. The presence of young digitally knowledgeable, fast expanding economies, large population, high mobile and internet penetration, and increasingly under-served SMEs and consumer markets across conventional financial markets boost rapid Fintech innovation in ASEAN.

According to the United Oversea Bank (2019), there were an increasing number of Fintech companies in all ASEAN countries from the year 2014 until 2019. There is a total of 2590 Fintech firms in ASEAN in which Singapore accounts for the highest number with 1,157 Fintech firms. In addition, there has been a significant surge in ASEAN's Fintech funding from 2014 with US\$ 35 million to US\$ 1,148 million in 2019. This indicates that development of Fintech in ASEAN is promising. Also, there is a notable rise in later stage funding in both 2018 and 2019 which further denote that investors are confident regarding the potential growth of Fintech in ASEAN. Overall, only Singapore displays a mature Fintech market while the rest of the countries are still in earlier stages of development. Countries such as Brunei Darussalam, Cambodia, Laos, and Myanmar show relatively nascent Fintech development compared to other countries.

There are various reports on the general trend of Fintech in ASEAN in terms of number of Fintech companies and funding but consumer intention to adopt Fintech in ASEAN still remain ambiguous. It is important to understand market demand in order to formulate an effective policy to boost Fintech development in ASEAN. Also, looking into past literatures, there are limited studies examining Fintech adoption through comparison of different ASEAN countries. The only available index is the "EY Fintech Adoption Index" which covers only Singapore among ASEAN 
countries. Thus, through the construction of a Fintech adoption composite index across ASEAN countries, this study seeks to fill the gap by integrating the most important dimensions as key indicators to help policy makers to gain a deeper understanding of Fintech in ASEAN from the customer's perspective.

The remainder of the study is arranged as follows. Section 2 elaborates on the conceptual framework and related past literature on Fintech adoption in ASEAN countries. Section 3 discusses the data and methodology involved in constructing the composite index. Next, Section 4 discusses the results obtained. Finally, Section 5 concludes the study.

\section{Literature Review}

Technology acceptance theory as shown in Figure 1 illustrates how people adopt to a new technology, developed by Davis et al. (1989). Based on this theory, perceived usefulness and perceived ease of use are the two main drivers influencing adoption. Perceived usefulness denotes the degree to which people believe that the technology is helpful, while perceived ease of use refers to the degree to which people feel that the technology is not complicated. External factors affect both perceived usefulness and perceived ease of use. These external factors are discussed empirically with the findings of the present study.

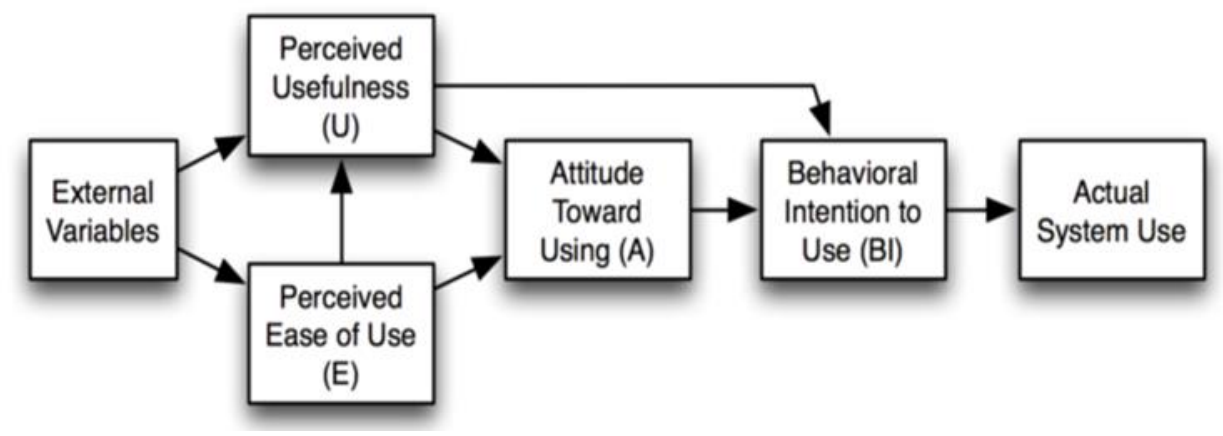

Figure 1. Technology acceptance theory

There were vast past studies of Fintech adoption from different perspectives. Most of the research works focused on the factors affecting Fintech adoption based on technology acceptance theory. Past studies showed that trust toward the Fintech is deemed to accelerate the adoption toward Fintech (Meyliana et al., 2019; Hu et al., 2019; Christina et al. 2019; \& Tun, 2019). Meyliana et al. (2019), Hu et al. (2019) and Christina et al. (2019) similarly used structural equation modelling to determine the factors affecting the Fintech adoption. The authors found that consumer trust toward Fintech does not affected by the perceived risk inherent, instead it depends on the ease of use and usefulness (Meyliana et al., 2019). This is mainly because factors such as Fintech's image, government provision and consumer innovation influence confidence level toward Fintech, which later boost the Fintech adoption rate indirectly (Hu et al., 2019). As substantiated by Christian et al. (2019), supports from government and vendor are able to boost the Fintech adoption through the active e-wallet services offering and training of merchants. The consumers are believed to be more adapting to the use of Fintech due to high digital intelligent and financial literacy (Morgan and Trinh, 2020; Chong et al., 2019). Also, the ease of use further encourages the Fintech adoption (Candra et al., 2020). Still, these studies focus only the factors affecting the adoption of Fintech through survey, but do not provide an overview on the Fintech adoption level across the ASEAN countries, which thus motivate the present study to do it.

Moreover, the only index study on Fintech adoption is the EY Fintech Adoption Index 2019 proposed by Ernst and Young Global Limited (2019). It was a one-year basis index conducted based on subjective survey, which employed the use of primary data to determine consumer adoption of Fintech and covers 27 countries in the worldwide such as China, India, Russia, Singapore, South Korea and so on. Their study revealed that the global Fintech adoptions are leading by both China and India with the presence of $87 \%$ of digitally active population in the market, and account for $64 \%$ of the global consumer adoption rate. It also showed that $96 \%$ of the global consumers are aware and more likely to adopt the money transfer and payment categories of Fintech, and the adoption of Fintech is largely driven by its attractive rates and fees. The findings are in line with the statistics from Armstrong (2017) in which China and India both accounted the highest digital active population in all the Fintech segments. Singapore as the only ASEAN countries being listed and surveyed in their study, they found out that $67 \%$ of Singaporeans adapt to Fintech services 
in 2019, a significant increase compared to $15 \%$ in 2015. Nevertheless, the Fintech adoption level in other ASEAN countries still remain unrevealed and therefore to be examined through this study.

Before constructing the conceptual framework of Fintech adoption index for ASEAN countries (hereinafter AFAI), a detailed understanding of the sub-sector of Fintech is required. Ernst and Young Global Limited (2018) highlighted the top three Fintech sector profiles in ASEAN are payments, loan apps or financing and money transfer or remittances. The study by Knewtson and Rosenbaum (2020) pointed out that the Fintech industry consists of four major areas: money alternatives, capital intermediation, investment technology and infrastructure. Money alternatives are firms providing services involving money, such as cryptocurrency or exbank payment systems while capital intermediation refers to insurtech, digital banking and lendtech. Investech denotes crowdfunding, algorithm trading, financial intelligence and investment apps. Finally, infrastructure involves credit technology and regtech. Thus, this study captures the adoption in these related sub-sectors of technologies such as mobile pos payment, digital commerce, crowdfunding, crowdinvesting, digital remittances, robo-advisors, crowdlending and marketplace lending. This is because a detail understanding on the demand of specific market segments toward a specific product will enhance the services and operational efficiency (Candara et al., 2020), and thus it is worth to include into the construction of AFAI in this study.

Nevertheless, several Fintech related indices are available with various goals from determining Fintech progress to examining adoption levels of Fintech in different countries. Those indices include the Fintech Index 2016 (Hieminga \& Lande, 2016), Index Performance Scores 2017 (Deloitte \& Global Fintech Hub Federation, 2017), Global Fintech Ranking (Ankenbrand \& Bieri, 2018), Global Fintech Hub Index 2018 (Ben et al., 2018), Global Fintech Adoption Index 2019 (Ernst \& Young Global Limited, 2019) and Global Fintech Index 2020 (Findexable Limited, 2019). Each of these indexes having different objectives. The authors make a meaningful comparison across the countries by determining the area required improvement through the scores generated. A better policy analysis and public communication are thus anticipated from their analysis. Out of all these indices, only the Fintech Adoption Index aims to study the adoption level of Fintech. The rest of the index prioritizes on the quantity, quality, and ecosystem assessment of Fintech. Also, most of the indices are on a city basis and do not cover all the ASEAN countries. Overall, there is limited discussion of the adoption level of Fintech, particularly in ASEAN countries. As aforementioned, the Fintech Adoption Index 2019, however, covers only Singapore among ASEAN countries. Past studies were based on the subjective survey, weighting and do not aim to study the trend of Fintech adoption over the time. Henceforth, the present study intends to fill the gap by constructing a composite index to determine the adoption level of Fintech, i.e. the AFAI based on a more objective-based methodology.

Apart from that, there are other composite measures found in different fields such as the Environmental Sustainability of Olive Farm (Gomex-Limon et al., 2020), ICT Development Index (ICT Data \& Statistics Division Telecommunication Development Bureau International Telecommunication Union, 2019), Network Readiness index (Dutta \& Lanvin, 2019), Cisco Digital Readiness Index (Cisco, 2019), and Regional Sustainable Development Index (Rahma et al. 2019). Such indices act as reference points to strengthen the construction of composite indicators. These indices are calculated using several famous methods, such as, but not limited to, principal component analysis, equal weighting, total limit normalisation, z-score, arithmetic mean aggregation, geometric mean aggregation, and entropy method. Many of these indices are calculated on a yearly basis to allow for year-round comparison. This study constructs the AFAI for three consecutive years to look into the trend to further fill the gap in Fintech's adoption pattern.

\section{Methodology}

\subsection{Data Descriptions}

In constructing the AFAI in this study, eight substantial dimensions have been identified to contain a total of 24 indicators, as shown in Table 1. These annual data are sourced from Statista, with a sample period from 2017 to 2019.

Table 1. Dimensions and indicators of AFAI

\begin{tabular}{ll}
\hline Dimension & Indicators \\
\hline D1: Mobile Pos Payment & Transaction value of mobile pos payment \\
\cline { 2 - 2 } & Users of mobile pos payment \\
\hline
\end{tabular}




\begin{tabular}{ll}
\hline & Average transaction value per user of mobile pos payment \\
\hline D2: Digital Commerce & Transaction value of digital commerce \\
\cline { 2 - 2 } & Users of digital commerce \\
\cline { 2 - 2 } & Average transaction value per user of digital commerce \\
\hline D3: Crowdfunding & Transaction value of crowdfunding \\
\cline { 2 - 2 } & Number of campaigns of crowdfunding \\
\cline { 2 - 2 } & Average funding per campaign of crowdfunding \\
\hline D4: Crowdinvesting & Transaction value of crowdinvesting \\
\cline { 2 - 2 } & Number of campaigns of crowdinvesting \\
\cline { 2 - 2 } & Average funding per campaign of crowdinvesting \\
\hline D5: Digital remittances & Transaction value of digital remittance \\
\cline { 2 - 2 } & Users of digital remittance \\
\cline { 2 - 2 } & Average transaction value per user of digital remittance \\
\hline D6: Robo-advisors & Assets under management of robo-advisor \\
\cline { 2 - 2 } & Users of robo-advisor \\
\cline { 2 - 2 } & Average assets under management per user of robo-advisor \\
\hline D7: Crowdlending & Transaction value of crowdlending \\
\cline { 2 - 2 } & Number of loans of crowdlending \\
\cline { 2 - 2 } & Average funding per loan of crowdlending \\
\hline D8: Marketplace lending & Transaction value of marketplace lending \\
\cline { 2 - 2 } & Number of loans of marketplace lending \\
\cline { 2 - 2 } & Average funding per loan of marketplace lending \\
\hline &
\end{tabular}

\subsection{Procedures to Construct AFAI}

There are several steps involved in constructing the AFAI. Firstly, the indicators (raw data) collected have to be normalised. This study uses the panel min-max normalisation formula, i.e. Equation (1) to normalise the indicators because it allows easier comparison across the year with a common scale.

$$
x_{i j}=\frac{x_{i j}-\min \left(x_{j}\right)}{\max \left(x_{j}\right)-\min \left(x_{j}\right)}
$$

Next, the normalised data are processed through the arithmetic mean (AM) formula in Equation (2) to generate the score of each dimension for each country:

$$
A M=\frac{\sum_{i=1}^{l} x_{i j}}{l}
$$

Three different methods of aggregation, i.e. AM, geometric mean (GM) and entropy method are used to obtain total index scores, respectively. The formula for GM is as shown:

$$
G M=\sqrt[n]{y_{i} \times \ldots \times y_{n}}
$$

The construction of the entropy method is slightly different from the AM and GM because it comprises weight calculation. Shannon (1948) proposed an objective weighting approach to determine the weight of each indicator. The entropy weight is calculated using the formula as follows: 


$$
w_{j}=\frac{\left(1-E_{j}\right)}{n-\sum_{i=1}^{n} E_{j}}
$$

where $E_{j}$ is calculated with the formula;

$$
E_{j}=-k \sum_{i=1}^{m} \rho_{i j} \operatorname{In} \rho_{i j}
$$

Where $k$ formula is as shown;

$$
k=\frac{1}{\operatorname{In}(m)}
$$

where the $\rho_{i j}$ is calculated through;

$$
\rho_{i j}=\frac{x_{i j}}{\sum_{i=1}^{m} x_{i j}}
$$

All the scores calculated by means of these three methods are then aggregated by taking the average value as the final index score, i.e. the AFAI in this study. The final index score is also ranked for ease of interpretation.

\section{Results and Discussions}

\subsection{Scores of Dimensions in Each Country}

Figures 2 to 4 demonstrate the score of each dimension contributing to the AFAI in each country. In Singapore, the advancement of Fintech's regulation due to the formation of the Payment Services Act 2019 has successfully led to consumer confidence in mobile wallet adoption. A high investment deal in payment for Singapore (United Oversea Bank et al., 2019) seems to be well worth it as consumer demand has shifted toward mobile wallets. As the leader of Fintech, Singapore shows the highest score in Fintech adoption across the year.

Indonesia also shows a significant growth in mobile pos payment in the year 2019. Most of the investment in Indonesia has gone into the alternative lending, yet the alternative lending adoption remained constant over three years. Fintech lending is projected to generate gross added value of IDR 35 trillion in Indonesia (PwC Indonesia, 2019). Based on this finding, government efforts in the field of alternative lending do not appear effective in increasing the acceptance level. These may result from poor financial literacy in Indonesia (Mariska, 2019).

Apart from that, the mobile pos payment system is increasingly being adopted in both Indonesia and the Philippines with increasing smartphone penetration and, a higher rate of mobile data consumption (The Paypers, 2019). Also, the Philippines Securities and Exchange Commission is still in the process of finalising the crowdfunding regulation in 2019 (Fintechnews Philippines, 2019) to increase its market access. However, these policy efforts have not been successful, given the marginal decrease in crowdfunding adoption in 2019. Unclear and ineffective rules and regulations fail to persuade consumers to adopt.

Both Thailand and Malaysia have seen a slight surge in all categories of Fintech adoption from 2017 to 2019 , indicating that both countries are moving ahead in a growing trend. Thailand shows a notable surge in Robo-advisor adoption in 2019 since Thailand Siam Commercial Bank, the largest commercial bank in Thailand launched the robo-advisor to manage its investment portfolio (Farida, 2019).

Moreover, a significant rise in mobile pos payment adoption in Vietnam indicates that the effort made by the government seems to have been effective and in line with what has been observed in the previous report stating that mobile phone transactions doubled from 2018 (United Oversea Bank et al., 2019). Most importantly, Vietnam received the highest investment in payment in 2019 resulting from two large deals with VNPay and MomoPay (United Oversea Bank et al., 2019), which further promoted mobile pos payment adoption.

Countries such as Brunei Darussalam, Cambodia, Myanmar, and Laos show a rising trend in mobile pos payment adoption. It is a common occurrence in both emerging and developing markets as digital payments are common in daily life. Also, uncertainty regarding other new innovative products hinders adoption in the early stages. Thus, more effort is required to promote the adoption of other Fintech products especially in countries such as Brunei Darussalam, Cambodia, Myanmar and Laos.

To sum up, external factors such as government regulatory efforts, as referred to in the theory of technology 
acceptance, are expected to raise the level of adoption through improving consumer trust in new innovative products. The clear and highly regulated Fintech environment in Singapore has produced the highest Fintech adoption, as an outstanding example. Besides, Fintech financial literacy and investment are supposed to impact Fintech consumer adoption in ASEAN countries.

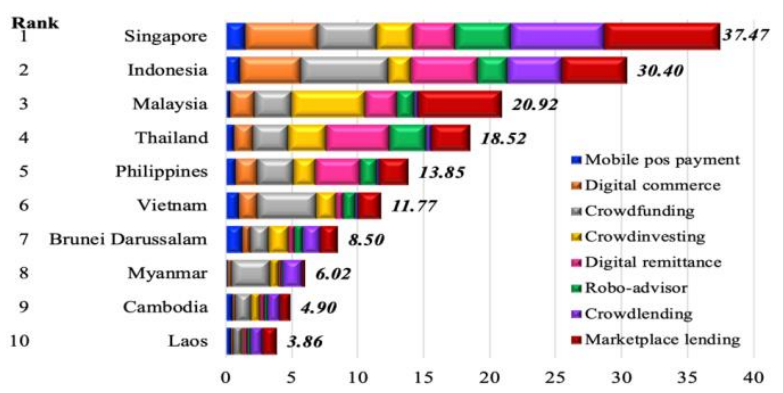

Figure 2. Ranking of ASEAN countries based on AFAI dimensional scores in 2017

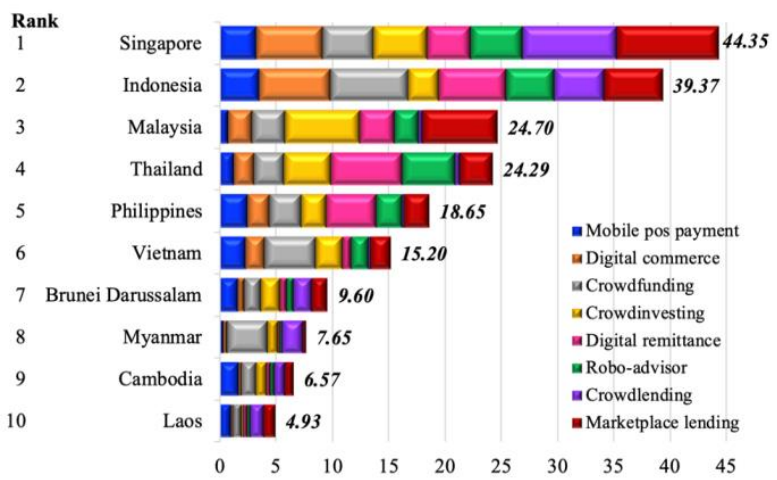

Figure 3. Ranking of ASEAN countries based on AFAI dimensional scores in 2018

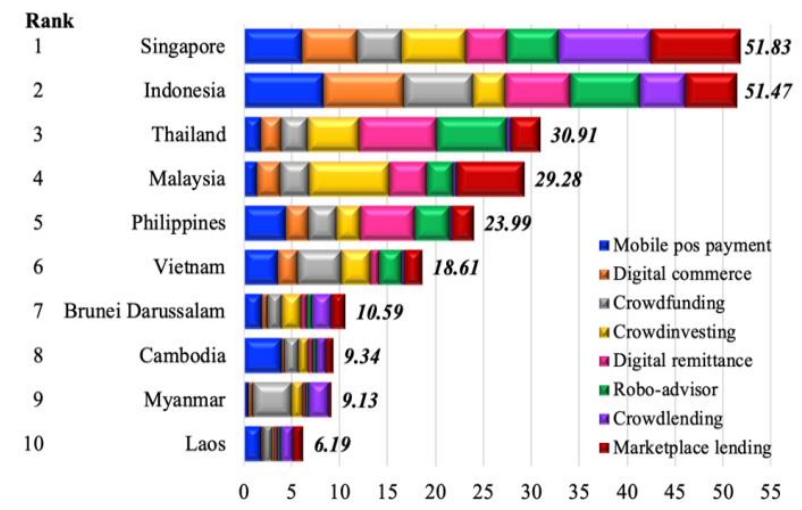

Figure 4. Ranking of ASEAN countries based on AFAI dimensional scores in 2019

\subsection{Scores and Rank of AFAI}

Table 2 depicts the ranks and scores of AFAI of each ASEAN country from 2017 to 2019. It is obvious that Singapore excels in embracing Fintech as it always holds the top rank across three years of comparison in Southeast Asia, and it is closely followed by Indonesia. Thailand surpassed Malaysia into the top 3 in 2019, while Malaysia fell to fourth place. The Philippines, Vietnam and Brunei scored better from 2017 to 2019, and still secure the position in fifth, sixth and seventh places, respectively among ASEAN countries. The adoption level of Fintech in Cambodia showed greater progress from 2018 to 2019, which outperformed Myanmar to be eighth in ranking. Although Laos is ranked at the bottom for the three consecutive years, its scores still show slight improvements from year to year. 
Table 2. Ranking of ASEAN countries based on AFAI

\begin{tabular}{|c|c|c|c|c|c|c|c|}
\hline \multirow[t]{2}{*}{2019 Rank } & \multirow[t]{2}{*}{ Country } & \multirow[t]{2}{*}{2019 Score } & \multirow[t]{2}{*}{$\Delta$ from 2018 to 2019} & \multicolumn{2}{|l|}{2018} & \multicolumn{2}{|l|}{2017} \\
\hline & & & & Rank & Score & Rank & Score \\
\hline 1 & Singapore & 51.83 & $\Leftrightarrow$ & 1 & 44.35 & 1 & 37.47 \\
\hline 2 & Indonesia & 51.47 & $\Leftrightarrow$ & 2 & 39.37 & 2 & 30.40 \\
\hline 3 & Thailand & 30.91 & $\Uparrow$ & 4 & 24.29 & 4 & 18.52 \\
\hline 4 & Malaysia & 29.28 & $\Downarrow$ & 3 & 24.70 & 3 & 20.92 \\
\hline 5 & Philippines & 23.99 & $\Leftrightarrow$ & 5 & 18.65 & 5 & 13.85 \\
\hline 6 & Vietnam & 18.61 & $\Leftrightarrow$ & 6 & 15.20 & 6 & 11.77 \\
\hline 7 & Brunei Darussalam & 10.59 & $\Leftrightarrow$ & 7 & 9.60 & 7 & 8.50 \\
\hline 8 & Cambodia & 9.34 & $\Uparrow$ & 9 & 6.57 & 9 & 4.90 \\
\hline 9 & Myanmar & 9.13 & $\Downarrow$ & 8 & 7.65 & 8 & 6.02 \\
\hline 10 & Laos & 6.19 & $\Leftrightarrow$ & 10 & 4.93 & 10 & 3.86 \\
\hline
\end{tabular}

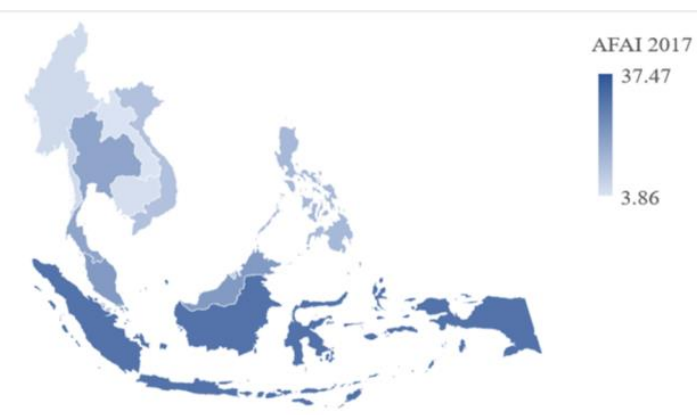

Figure 5. AFAI 2017 geographical heat map

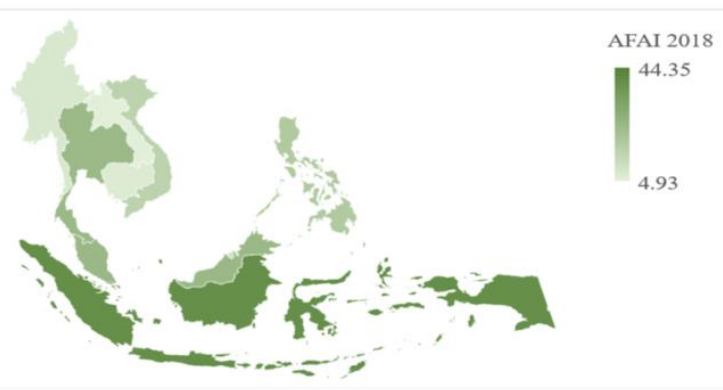

Figure 6. AFAI 2018 geographical heat map

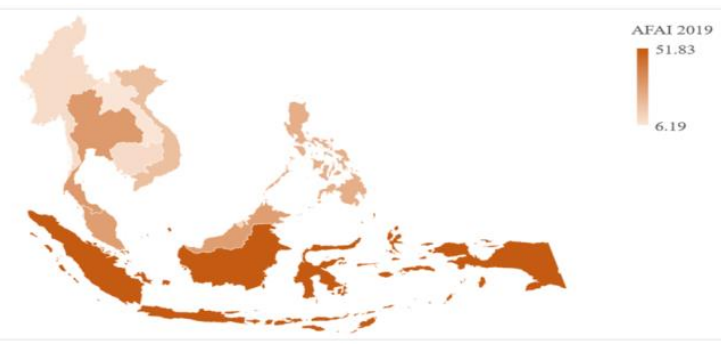

Figure 7. AFAI 2019 geographical heat map 


\subsection{Sensitivity Analysis}

The sensitivity analysis is examined. Firstly, Figure 8 indicates that all three methodologies provide close scores for all years. The result from the radar diagram indicates that the methodologies provide an accurate measure of AFAI.

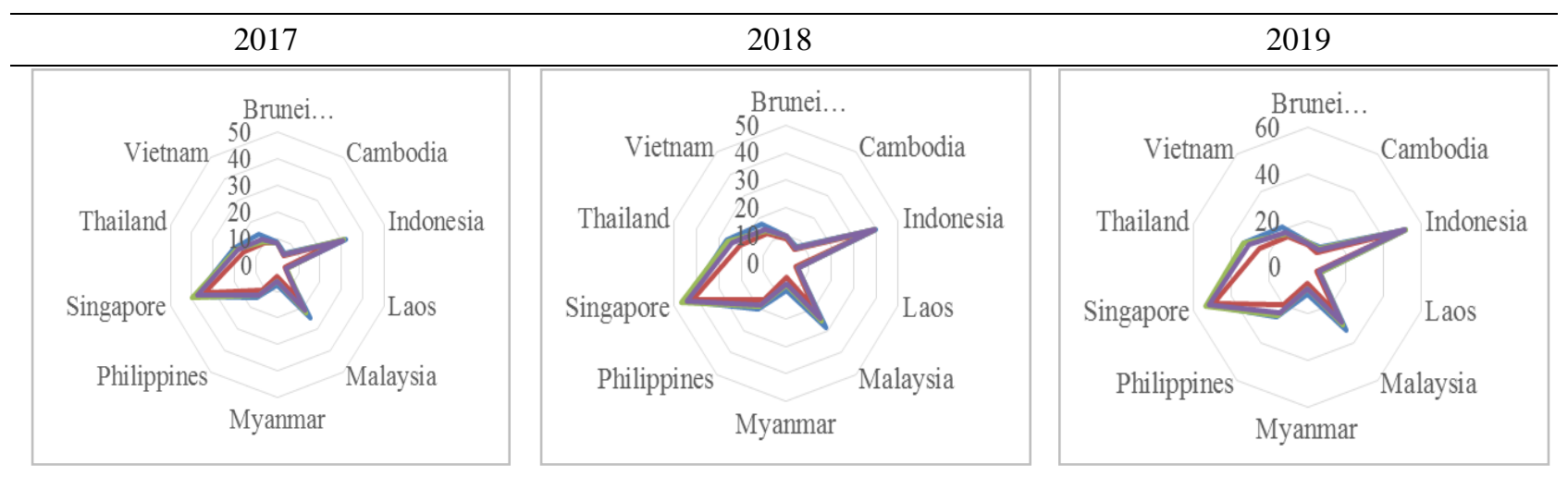

-AFAI_A -AFAI_G - AFAIE

Figure 8. Sensitivity of AFAI based on different index aggregation methods

Notes: AFAI_A refers to ASEAN Fintech Index based on arithmetic mean aggregation, while AFAI_G is based on geometric mean aggregation and AFAI_E is based on entropy method. AFAI indicates the final index score taking the average of AFAI_A, AFAI_G and AFAI_E.

\section{Conclusions}

This study investigates the consumer adoption level of Fintech in different sub-sectors through the construction of a composite index called AFAI, on an annual basis for the years of 2017 to 2019. From the results, Fintech adoption in countries with nascent Fintech development such as Brunei Darussalam, Cambodia, Myanmar and Laos are relatively low compared to countries with emerging Fintech development such as Indonesia, Malaysia, the Philippines, Thailand and Vietnam while countries with mature Fintech development like Singapore show relatively high adoption rate. Overall, the ASEAN countries showed an increasing trend of Fintech adoption from 2017 to 2019.

Moreover, looking into the details of the scores for each dimension in different countries, mobile pos payment adoption is growing in all ASEAN countries. Consumers in nascent Fintech development countries are more likely to adopt the mobile pos payment while consumers in countries with emerging Fintech development show different adoption intentions in different Fintech sub-categories due to the different policy development of focus in each country. Most significantly, Singapore with its mature Fintech market has a relatively balanceed consumer adoption across all different sub-sectors. This implies that Singapore has a well-balanced Fintech development in all sub-sectors.

Thus, based upon these results, this study suggests that more efforts should be made in countries such as Brunei Darussalam, Cambodia, Laos and Myanmar to boost consumer adoption in different categories of Fintech. Since these countries have relatively lower adoption rates compared to others, it is important to start with basic education by providing the public with up-to-date information on the introduction of digitalized remedies. At the same time, basic infrastructure and information technology should be a focus in countries such as Brunei Darussalam, Cambodia, Laos and Myanmar. Indonesia, Malaysia, the Philippines, Thailand and Vietnam should collaborate not only with Singapore but also others countries around the world to become a successful Fintech hub.

In addition, government may offer initiatives to local investors to expand Fintech in the businesses especially in countries with nascent and emerging Fintech development. Those initiatives act as accelerator of Fintech growth in ASEAN countries. In short, this study provides a quick view on the trend and Fintech adoption phenomenon in ASEAN countries. The findings obtained through visualization not only can enhance the interpretability for decision makers, it is also simple, informative and straightforward for laymen to understand the Fintech adoption scenario in the region. A better understanding on the Fintech adoption scenario can help to address different market demand 
conditions, thus, the business and public are able to make a better investment decision of Fintech-related from our findings.

There are some limitations in this study. The use of secondary data in this study covers a short period of year and it focuses only on the ASEAN countries. This study therefore suggests that future research should cover a longer time period or broader fields involved in the assessment of Fintech indexes. Revealing the Fintech adoption level for more countries is one of the future directions too. In addition, to better capture the dynamic changes in the future market, this study proposes that future research should review the use of component series in the construction of Fintech adoption index from time to time. Also, investigation of particular factors and reasons for the adoption of Fintech in various sub-sectors is encouraged in future studies.

\section{Acknowledgements}

Financial supports by Universiti Malaysia Sarawak (UNIMAS) and Fundamental Research Grant Scheme (F01/FRGS/1866/2019) are gratefully acknowledged.

\section{References}

Ankenbrand, T., \& Bieri, D. (2018). Where are the best fintech centers?. Retrieved from https://innovation.thomsonreuters.com/content/dam/openweb/documents/pdf/innovation/case-study/ankenbrand -thomas-bieri-denis-ifz-fintech-ranking-180530.pdf

Armstrong, M. (2017). FinTech adoption rates. Retrieved from https://www.statista.com/chart/10012/fintech-adoption-rates/

Ben, S., Lv, J., Qian, X., Hu, K., Luo, D., Xu, Z., ... Yang, L. (2018). The future of finance is emerging: New hubs, new landscapes-Global fintech hub report. Retrieved from https://www.jbs.cam.ac.uk/faculty-research/centres/alternative-finance/publications/2018-global-fintech-hub-rep ort/\#.XyKDZhMza3I

Bettinger, A. (1972). Fintech-A series of 40 time shared models used at manufacturers hanover trust company. Interfaces, 2(4), 62-63.

Chong, T. P., William, C. K. S., Yip, Y. S., Chan, P. Y., Julian, T., H. L., \& Ng, S. S. (2019). An adoption of Fintech service in Malaysia. South East Asia Journal of Contemporary Business, Economics and Law, 18(5), 134-147.

Christian, S., Wiradinata, T., Herdinata, C., \& Setiobudi, A. (2019). Environmental factors affecting the acceleration of financial technology (Fintech) adoption by SMEs in the East Java Region. 8th International Conference on Entrepreneurship and Business Management (ICEBM 2019) UNTAR, 145, 380-385. https://doi.org/10.2991/aebmr.k.200626.065

Cisco. (2019). Cisco global digital readiness index 2019. Retrieved from https://www.cisco.com/c/en/us/about/csr/research-resources/digital-readiness.html

Davis, F. D., Bagozzi, R. P., \& Warshaw, P. R. (1989). User acceptance of computer technology: A comparison of two theoretical models. Management Science, 35(8), 982-1003. https://doi.org/10.1287/mnsc.35.8.982

Deloitte, \& Global Fintech Hub Federation. (2017). The connecting global fintech: Interim hub review 2017. Retrieved https://www2.deloitte.com/tr/en/pages/finance/articles/a-tale-of-44-cities-global-fintech-hub-federation-gfhf-co nnecting-gl obal-fintech-hub-report.html

Dutta, S., \& Lavin, B. (2019). The network readiness index 2019: Towards a future-ready society. Retrieved from https://networkreadinessindex.org/

Ernst, \& Young Global Limited. (2018). ASEAN fintech census 2018. Retrieved from https://www.ey.com/en_sg/financial-services/asean-fintech-census-2018

Ernst, \& Young Global Limited. (2019). Global fintech adoption index 2019. Retrieved from https://www.ey.com/en_gl/ey-global-fintech-adoption-index

Farida, O. (2019, November 22). Thailand's Siam commercial bank launches robo-advisor, is reportedly planning to spin off its fintech branches. Retrieved from https://www.crowdfundinsider.com/2019/11/154380-thailands-siam-commercial-bank-launches-robo-advisor-isreportedly-planning-to-spin-off-its-fintech-branches/

Findexable Limited. (2019). The global fintech index 2020. Retrieved from 
https://findexable.com/wp-content/uploads/2019/12/Findexable_Global-Fintech-Rankings-2020exSFA.pdf

Hieminga, G., \& Lande, F. (2016). The fintech index: Assessing digital and financial inclusion in developing and emerging countries. ING Economics Department. Retrieved from https://www.ing.nl/media/ING_EBZ_fintech-index-report_tcm162-116078.pdf

Hu, Z., Ding, S., Li, S., Chen, L., \& Yang, S. (2019). Adoption intention of fintech services for bank users: an empirical examination with an extended technology acceptance model. Symmetry, 11(3), 1-16. https://doi.org/10.3390/sym11030340

ICT Data, \& Statistics Division Telecommunication Development Bureau International Telecommunication Union. (2019). The ICT development index (IDI): Conceptual framework and methodology. Retrieved from https://www.itu.int/en/ITU-D/Statistics/Pages/publications/mis2017/methodology.aspx

Mariska, D. (2019, October 30). Financial literacy, security and inclusion low among Indonesians: Study. Retrieved from https://jakartaglobe.id/business/financi al-literacy-security-and-inclusion-low-among-indonesians-study/

Meyliana Fernando, E., \& Surjandy. (2019). The influence of perceived risk and trust in adoption of fintech services in Indonesia. CommIT (Communication and Information Technology) Journal, 13(1), 31-37.

Morgan, P. J., \& Trinh, L. Q. (2019). Fintech and financial literacy in Viet Nam. Retrieved from https://www.think-asia.org/handle/11540/12116

Philippines, F. (2019, July 10). Philippines' regulators issues new crowdfunding rules. Retrieved from https://fintechnews.sg/32158/fintechphilippines/philippines-regulator-sec-crowdfunding-startup-investment/

Puschmann, T. (2017). Fintech. Business \& Information Systems Engineering, 59(1), 69-76. https://doi.org/10.1007/s12599-017-0464-6

PwC Indonesia. (2019). Indonesia's fintech lending: Driving economic growth through financial inclusion. Retrieved from https://www.pwc.com/id/en/fintech/PwC_FintechLendingThoughtLeadership_ExecutiveSummary.pdf

Rahma, H., Fauzi, A., Juanda, B., \& Widjojanto, B. (2019). Development of a composite measure of regional development in Indonesia. Sustainability, 11, 1-16. https://doi.org/10.3390/su11205861

Shannon, C. E. (1948). A mathematical theory of communication. The Bell System Technical Journal, 27, 379-423. https://doi.org/10.1002/j.1538-7305.1948.tb01338.x

Soriano, M., Ziegler, T., Umer, Z., Chen, H., Jenweeranon, P., Zhang, B., ... Liu, K. (2019). The ASEAN fintech ecosystem benchmarking study. Retrieved from https://www.jbs.cam.ac.uk/faculty-research/centres/alternative-finance/publications/the-asean-fintech-ecosystem -benchmarking-study/

The Paypers. (2019). Payment methods report 2019-Innovations in the Way We Pay. Retrieved from https://thepaypers.com/reports/payment-methods-report-2019-innovations-in-the-way-we-pay-2/r779461

Tun, P. M. (2020). An investigation of factors influencing intention to use mobile wallets of mobile financial services providers in Myanmar. The Asian Journal of Technology Management, 13(2), 129-144. https://doi.org/10.12695/ajtm.2020.13.2.3

United Oversea Bank \& Pricewaterhouse Coopers Risk Services and Singapore FinTech Association. (2019). Fintech in ASEAN from start-up to scale-up. Retrieved from uob.com/fintech2019

Zhang, X., Zhang, J., Wan, G., \& Luo, Z. (2020). Fintech, growth and inequality: Evidence from China's household survey data. Singapore Economic Review. https://doi.org/10.1142/S0217590819440028

\section{Copyrights}

Copyright for this article is retained by the author(s), with first publication rights granted to the journal.

This is an open-access article distributed under the terms and conditions of the Creative Commons Attribution license (http://creativecommons.org/licenses/by/4.0/). 